\title{
Cuento
}

\section{TODOS CONTRA ERNESTO}

\author{
Germán Valenzuela RodrígueZ ${ }^{1}$
}

"Estoy en Lima, en el inmenso pueblo, cabeza de los falsos wiracochas...Al inmenso pueblo de los señores hemos llegado y lo estamos removiendo. Con nuestro corazón lo alcanzamos, lo penetramos..."

J.M. Arguedas. Tupac Amaru Kamaq Taytancltisman Haylli-Tak. Lima. 1962.

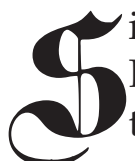
ientes cómo tu cuerpo cae contra el piso. El polvo se introduce por tus ojos y por tu nariz. Ernesto y los niños lindos se estan riendo. Se ríen de ti. Te toman de los brazos y de las piernas. Quieren asfixiarte. Por eso recogen montoncitos de tierra que intentan hacer ingresar por tu nariz y por tu boca. Sientes el contacto con esa estructura ácida y rugosa que ahora intenta fusionarse con tu garganta, con tu lengua. No. Déjenme. Me voy a ahogar. Déjame Ernesto-dices. Déjenme niños lindos-murmuras con menos fuerza. Voy a caminar en cuatro patas y ladraré como un perro pero quiero que me suelten. Ustedes son muchos y yo estoy sólo con mis dos amiguitos. Es probable que no escuchen tus palabras porque se están riendo y puedes observar la perfección de sus dientes blanquitos. Ernesto está frente a ti, dirigiéndose a los niños lindos. Realmente son lindos. Puedes mirarlos si haces esfuerzos pues tus ojos están llenos de tierra. Te arden y para poder ver las imágenes, estás obligado a mover tus pestañas. Ahí están todos, riéndose como seres idénticos. Como si fueran hermanitos. Así es Jamayito. Esos niños tienen ojos grandes, tan grandes que parece que se les fueran a salir de las órbitas. Sus ojitos están pintados del color del cielo o de las hojas de los árboles en primavera.

No volverás a ver sus ojitos- Jamayito. No son como los tuyos, pequeñitos y tristes. Porque sus cabellos son también del color del oro, Jamayito aunque tú dices que tienen el color de la caca.

$\cdots$

Nunca debí pedir que me inviten a sus juegos. Me lo dijiste Rodolfito. Pero tú Jamayito me indicaste que debía ser fuerte y no llorar. ¿Cómo tendré que hacerlo, si me están pateando el estómago y los huevos? Ese dolor es muy fuerte. Todos me patean con sus botas de cuero, y ya no les importa ensuciar sus blancos trajes con la tierra ni con el lodo. Ahora no. Y siguen, $\mathrm{y}$ siguen, por lo que he decidido morderme la lengua y comer la tierra que han puesto en mi boca, en mi garganta, en mi nariz, en mis oídos. Pero no se detienen. Y todo lo organiza el niño Ernesto. El siempre me ha odiado. Creo que es porque soy fuerte y no me enfermo nunca. Hasta parece que mis heridas sanaran rápidamente. No como al niño Ernesto que es delicadito y siempre quiere que le limpien las heridas y las coloquen ocultas debajo de

1 Médico internista y cardiólogo. 
las gasitas untadas de medicamentos. Yo sólo me curo con telitas de araña, Jamayito. Qué pena que no puedas decírselos. ¿Por qué no te atreves?. Tampoco tú Rodolfito. Ni siquiera tú, que puedes jugar con ellos. Ustedes dos son también cobardes como ellos. ¿Por qué no me defienden, carajo?

EntonceselniñoErnestosemeacercatocándome los pelos mientras se ríe a carcajadas porque son duros como espinas. Todos comienzan a reír. Y se acerca a mi boca diciéndome que mis dientes son de perro y que huelen a caca de perro, mientras rompe mi camisa e intenta abrir mi pantalón. No tengo correa, por lo que consigue en pocos minutos dejarme desnudo a la vista de todos sus amiguitos.

-Es negro, es negro-dicen. Nooooooooo -Es cholo porque tiene el pelo duro. Siiiiiiiiiiiresponden a un mismo ritmo como un coro de querubines, mientras Ernesto se me acerca colocándome de costado y observando que mis nalgas tienen una huella. Jamás escuché hablar a mis padres de esa huella, pero Ernesto les explica riéndose que es la mancha de los cholos, porque todos los cholos la tienen, porque soy un cholo, entonces. De repente tienen razón y debo resistir, mereciéndome todos sus golpes. Golpéenme más. Tienen razón niños lindos. Golpéenme que yo me merezco esto, por tener manchitas en las nalgas y ser tan oscuro que a su lado parezco una mancha grande. Ahora sí déjenme. No voy a llorar. No voy a llorar.

¿Por qué lloras Ernesto? ¿Por qué lloran todos? ¿Por qué se van?

No voy a llorar. Me pongo de pie. Caramba. Esa sangre no deja de caer por mi nariz. Debo apretarla fuerte Jamayito. ¿No sabes cómo hacer que se detenga?. Claro, Rodolfito. Lo haré como tú dices. Y como siempre tendrás razón. A mí las heridas se me curan rápido. ¿entiendes Rodolfito? Tú eres sabio porque juegas con ellos, amigo. Le diré al niño Ernesto que me perdone pero intentaré jugar con él un juego nuevo. Un juego donde yo sea un perro fiel.

$\cdots$

Ahora estoy bonito como un día alegre. Mañana les diré a los niños lindos para jugar. Seguro me dirán que sí. Sí puedes jugar porque eres un niño lindo. Miren mi pantalón de lino verde. Y mi camisa roja que parece brillar. Yo soy un niño lindo. Me convertí en un niño lindo ayer. $Y$ ninguno de ustedes me dijo cómo hacerlo. Tuve que averiguarlo sólo, escuchando las conversaciones de mis tíos que ahora son como mis padres, porque los míos dicen que están en el cielo, pero yo les hablo cuando le hablo a la tierra.

Noto que mi cabello está rojo y pronto se pondrá del color del sol, porque por las mañanas el sol sale entre las montañas, rojo y gigantesco; y por las tardes se vuelve amarillo, y se va a vivir a los cielos. Ahí donde dicen que están mis papás, pero yo no les creo porque no puedo verlos.

¿Y qué dirán ellos de mí? Espero que entiendan que a pesar de ser un niño lindo, seguiré siendo su hijo, y sólo jugaré con los otros niños lindos los días jueves. El resto de días seguiré siendo normal. Aunque es probable que no pueda volverme normal, o no quiera volver a serlo. $Y$ no se rían, niños lindos. Cállense que cuando se ríen así, me provoca buscarlos y sacarles la mierda.

Sobre todo a ti, Jamayito. Te voy a romper la nariz y no volveré a escucharte. ¿Y por qué te metes Rodolfito? Tú me has dicho que soy un niño lindo, pero ¿por qué quieres defenderlo? 
Eso no lo entiendo. Deberías ser mi amigo porque tú quieres ser también un niño lindo. ¿No lo crees? ¿Por qué se ríen? Cállense, cállense. Voy a romperlo todo. Y golpeo mis puños contra las paredes y contra el espejo que refleja mi imagen de verde y rojo, y mi cabello que es la señal de mi conversión en un niño lindo.

Por eso he comenzado a untar mi piel con la sangre que brota de mis puños. Tengo que tener cuidado con mis ropas y sólo colocarla en mi rostro. ¿Y ese reflejo en el espejo roto?. Estoy oscurito, con los ojos caídos, los labios gruesos y con la nariz grande y torcida hacia el suelo. Tenías razón Jamayito.

Cállense, cállense. Dejen de reír. ¿Cómo hacen ustedes para que los escuche si tengo los oídos cerrados y cubiertos con toda la fuerza de mis manos?

Niño Ernesto. Ven. Quiero jugar contigo.

Al inicio no aceptarás. Me dirás que no juegas con cholitos. Pero te insistiré, rogándote... para que mires que realmente quiero hacerlo.

Si quieres seré tu perro-le diré. Y él aceptará. Entonces comenzaremos a jugar. Y sólo tú sabrás que también juegan Rodolfito y Jamayito. Claro. El niño Ernesto no puede verlos, pero están vivos. Están vivos porque los ves clarito.

Jamayito tiene una camisa blanca de mangas cortas y un pantaloncito de tela gris. Camina descalzo como cuando tú llegaste a la hacienda por primera vez, y sus ropitas tienen huecos y parecen haber perdido sus colores.

Intentas mirarlo de reojo y mueves los labios para que no se de cuenta que está contigo. Pero no están sólos los tres, porque también está Rodolfito. El te hace señales diciéndote que te calles y que te portes bien. Prefieres no hacerle caso. No te gusta Rodolfito. Mira cómo está vestido. Con pantalón y camisa de lino blancos. Tan limpio que parece un angelito. Él te ha dicho que no debiste jugar a los perritos, pero a ti no te importa lo que diga, pues no se atreve a amenazarte como lo hace Jamayito.

Los minutos transcurren y te concentras en el niño Ernesto olvidándote que ahora son tres y él está solito. Aceleras el paso y comienzas a correr alejándote de la casa grande. Sientes sus pasos cerca. Corres rápido pero tus ojotas se pegan al suelo mientras que sus botas parecen haber sido diseñadas para volar sobre el suelo. Te alcanza primero tocándote, para luego jalarte los cabellos. Ahora debes ser mi perro, lo escuchas decir. $\mathrm{Y}$ aprisiona tus cabellos tan fuerte que sientes un dolor en tu frente y en tus ojos.

Te detienes. Has aprendido a resistir y a cumplir con tus promesas. Recuerdas las conversaciones de tus tíos y de todas las veintiún personas: doce hombres (tú eres uno de ellos) y nueve mujeres, quienes te acompañan en una de las casas pequeñas ubicadas alrededor de la casa grande.

Han coincidido al decirte que en el pasado la tierra era gobernada por gente como ellos. Luego fueron invadidos. Sometidos. Engañados. Después explotados, humillados. Ofendidos por esos seres con piel, ojos, cabellos y almas descoloridas. ¿Qué harían?

¿Qué intentarían?-recuerdas haberte preguntado mientras escuchabas.

Y tú los entiendes observando sus manos, sus labios. Memorizando sus palabras como si fueran a repetirse en tu mente siempre. Ellos dicen que deben vengarse. Que tarde o 
temprano volverán a mandar en ese mundo. Porque ese mundo era sólo de ellos. Porque el mundo debía cambiar y ellos debían cambiar el mundo.

Claro. Ahora lo recuerdas todo. Cuando Ernesto te ha colocado en cuatro patas y golpea tu barriga y tus mejillas con sus brazos y piernas. Pero no sientes dolor. Tú quisiste comenzar ese juego. Por ello resistes el dolor de las piedras y las espinas sobre tus palmas endurecidas por tu tiempo y el tiempo de todos los tuyos. Resistes y sigues soportando el peso sobre tu espalda. ¿Hacia dónde te lleva? Camina, cholo-pareces escuchar. Camina, perro -te dice. $Y$ crees que eres un perro porque es un juego, pero en una de esas ha dicho pegho, de la manera tan extraña como suele decir las cosas cuando está exaltado o cuando está con los otros niños lindos. Te parece raro no ser un perro porque habías aceptado serlo. Sientes un peso enorme en tu espalda y cómo late tu corazón a punto de salirse por tus ojos y provocar la caída de un mar de lágrimas nacido de tu alma. Pero no. Tienes el rostro seco. Los ojos secos. Más secos que nunca. Entonces te golpea. Se pone de pie.

-Avanza pegho. Pegho. Pegho-dice y mirándote a los ojos escupe tu rostro tres veces. Tus labios tiemblan ahora y no sientes calor sino un extraño frío en tus brazos. Te pones de pie. Golpeas su rostro con tus puños furibundos llenos de pedazos de tierra y espinas. Lo golpeas tantas veces viendo cómo se desploma frente a ti, porque sus palabras no han llegado a conmoverte, pero al final se convirtieron en llantos, sollozos o ruegos.
Y al caer su cabeza colisiona con una piedra y comienza a sangrar frente a tus ojos. El frío no cesa. Continúas golpeando su barriga, su espalda, consiguiendo que más sangre salga de su boca y de sus ojos. Sigue tendido. No te importa si respira o no.

Tomas la piedra y lo golpeas en el tórax mientras escuchas nuevamente la voz de tus acompañantes.

-Sácale el corazón-dice Jamayito.

-No lo mates aún. Eres sólo un niño, escuchas la vocecita aguda de Rodolfito. Pero no te importa. Quieres que el frío escape de tu cuerpo y comienzas a golpear su pecho, ahora descubierto, con una piedra filuda hasta hacer un hueco en su escudo de huesos. Es un escudo débil-piensas. Mis piedras son más fuertes que tus huesos. Mis piedras son la extensión de mis manos, repites en voz baja.

Miras ese paisaje. El enemigo está vencido. El niño Ernesto no volverá jamás a burlarse de ti. Te has convertido en un hombre por cumplir con las órdenes de los hombres mayores de la casa pequeña.

Calmado, introduces tus manos, sintiendo ese líquido viscoso coagulándose en tus ropas. Localizas ese corazón que ahora no late. Lo arrancas. Levantas tus brazos hacia el sol. Besas la tierra santa.

Cubres tus cabellos y pedazos de tu piel con ese líquido rojo que no es tuyo porque no ha salido de ti.

Ya no tienes frío. Ahora estás tranquilo. No te importan las voces confundidas de tus amigos. 